\title{
FNAB and calcitonin wash-out during exenatide therapy
}

\author{
Bengur Taskiran \\ Eskisehir Yunus Emre State Hospital, Turkey \\ Department of Endocrinology
}

\section{INTRODUCTION}

According to adverse effect registry system, medullary thyroid cancer (MTC) is 4.73 times higher among glucagon like peptide-1 (GLP-1) agonist users. GLP-1 agonists are witheld in case of MTC or MEN. Serum calcitonin $(\mathrm{Ct})$ does not increase to diagnostic level in small and nonmetastatic MTC. Since the clinical significance of C cell hyperplasia $(\mathrm{CHH})$ and micro MTC is unknown, recommendation about routine serum $\mathrm{Ct}$ evaluation before therapy is not settled. Ct wash-out of fine needle aspiration biopsies (FNAB) is a valuable method in detecting local recurrences and lymph node metastases. We report cytology and $\mathrm{Ct}$ wash-out results of FNAB in type 2 diabetic patients receiving exenatide.

\section{METHODS}

Eleven male and 66 female patients (31-76 years old) receiving exenatide therapy (5 mcg bid for the first month and $10 \mathrm{mcg}$ bid afterwards) for type 2 DM were evaluated. None of them had a history of pancreatitis, known thyroid cancer, and MEN. Nodules less than $1 \mathrm{~cm}$ with suspicious features (microcalcification, border irregularity, increased vascularity) and over $1 \mathrm{~cm}$ were biopsied. The same syringe used for FNAB was washed with $1 \mathrm{~mL}$ saline. Serum $\mathrm{Ct}$ and $\mathrm{Ct}$ in wash-out fluid from FNAB were measured using chemiluminescence immunoassay (CLIA).

\section{RESULTS}

Sixty three $(80 \%)$ patients quit exenatide bid due to nausea $(n=9)$ increased amylase level $(n=1)$, suspicion of thyroid cancer $(n=2)$, high A1c above target $(n=16)$, headache $(n=1)$, absence of weight loss effect $(n=19)$, and patients' unwillingness to continue $(n=15)$.

Daemographic and laboratory data are shown in Table 1. Of 45 patients with basal US evaluation, 19 had micronodules (43\%) and 14 had nodules (33\%) over $1 \mathrm{~cm}$ in size. Three had normal US findings and 11 had heterogenous thyroid. FNAB results are presented in Table 2.

One patient without baseline value, had Ct level of $482 \mathrm{pg} / \mathrm{ml}$ at the 5 th month of therapy. She had multinodular goiter where the largest hypoechoic nodule was $23^{*} 13 \mathrm{~mm}$ in the left lobe and $19^{*} 13 \mathrm{~mm}$ in the right lobe on US. She had traffic accident while thyroidectomy was planned and then was lost follow-up. Since basal Ct level and FNAB were absent, the relation between high $\mathrm{Ct}$ level and exenatide therapy could not be established.

The other patients had normal Ct values both at baseline $(n=43,2.26 \pm 0.66$ $\mathrm{pg} / \mathrm{ml}$ ) and during follow-up $(\mathrm{n}=65,2.28 \pm 0.62 \mathrm{pg} / \mathrm{ml})$. Three patients developed micro PTC. Duration of exenatide therapy before diagnosis of PTC was $5.5 \pm 3.8$ mos (2-11 mos). None of FNAB and histologic evaluation of papillary thyroid cancer (PTC) samples revealed $\mathrm{CHH}$. Ct wash-out levels of 21 patients were normal $(2.47 \pm 1.21 \mathrm{pg} / \mathrm{ml})$.

\section{CONCLUSION}

Normal serum and wash-out $\mathrm{Ct}$ levels and FNAB findings suggest exenatide is safe in terms of MTC and CCH. Because of the index case it may be prudent to do basal US and FNAB as needed at least before therapy.

Effect of GLP-1 analogue on thyroid tissue is still obscure. In vitro human TT C cells bear scanty GLP-1 receptors and do not show functional response to GLP-1. Sporadic $\mathrm{CHH}$ can be incidentally observed in neighbourhood of follicular derived thyroid tumours, during aging, or in chronic autoimmune thyroiditis. Aberrant GLP-1 receptor positivity in PTC may be important in patients receiving GLP-1 analogues especially in case of subtotal thyroidectomy/lobectomy or microcarcinomas.

Table 1. Daemographic and laboratory data of subjects

\begin{tabular}{|l|c|c|}
\hline & Mean \pm SD & Range \\
\hline Age (years) & $53.88 \pm 8.77$ & $31-76$ \\
\hline DM duration (years) & $7.22 \pm 5.09$ & $1-21$ \\
\hline Exenatide therapy duration (months) & $7.77 \pm 5.84$ & $1-24$ \\
\hline Baseline weight $(\mathrm{kg})$ & $102.26 \pm 13.68$ & $78.00-152.30$ \\
\hline Weight loss during follow-up $(\mathrm{kg})$ & $6.70 \pm 5.71$ & $0-26.90$ \\
\hline Baseline BMI $\left(\mathrm{kg} / \mathrm{m}^{2}\right)$ & $41.45 \pm 4.94$ & $35.15-60.24$ \\
\hline Follow-up BMI $\left(\mathrm{kg} / \mathrm{m}^{2}\right)$ & $40.69 \pm 4.95$ & $31.88-58.94$ \\
\hline Baseline serum Ct $(\mathrm{pg} / \mathrm{ml})$ & $2.26 \pm 0.66$ & $2.00-5.70$ \\
\hline Follow-up serum Ct $(\mathrm{pg} / \mathrm{ml})$ & $2.28 \pm 0.62^{*}$ & $2.00-4.90$ \\
\hline Follow-up Ct wash-out $(\mathrm{pg} / \mathrm{ml})$ & $2.94 \pm 2.43^{*}$ & $2.0-11.60$ \\
\hline Baseline TSH $(\mathrm{IU} / \mathrm{ml})$ & $2.28 \pm 1.53$ & $0.05-8.80$ \\
\hline Baseline glucose $(\mathrm{mg} / \mathrm{dl})$ & $165.39 \pm 58.15$ & $88-350$ \\
\hline Baseline Hemoglobin A1c $(\%)$ & $8.21 \pm 1.46$ & $5.45-13.18$ \\
\hline Follow-up Hemoglobin A1c $(\%)$ & $7.45 \pm 1.13$ & $5.80-12.20$ \\
\hline Decrease in Hemoglobin A1c $(\%)$ & $0.73 \pm 1.40$ & $0-4.83$ \\
\hline Baseline LDL $(\mathrm{mg} / \mathrm{dl})$ & $116.50 \pm 30.93$ & $33-195$ \\
\hline Baseline HDL $(\mathrm{mg} / \mathrm{dl})$ & $48.16 \pm 9.63$ & $31-76$ \\
\hline Baseline triglyceride $(\mathrm{mg} / \mathrm{dl})$ & $170.38 \pm 72.49$ & $58-438$ \\
\hline Baseline amylase $(\mathrm{IU} / \mathrm{ml})$ & $47.10 \pm 16.77$ & $16-96$ \\
\hline Follow up amylase $(\mathrm{IU} / \mathrm{ml})$ & $61.85 \pm 28.35$ & $21-177$ \\
\hline Baseline creatinine $(\mathrm{mg} / \mathrm{dl})$ & $0.75 \pm 0.18$ & $0.09-1.25$ \\
\hline Follow up creatinine (mg/dl) & $0.86 \pm 0.21$ & $0.56-1.74$ \\
\hline
\end{tabular}

* The index case with high follow-up serum CT $(482 \mathrm{pg} / \mathrm{ml})$ was excluded. The patient was lost follow-up before sampling and thyroidectomy

Table 2. FNAB results

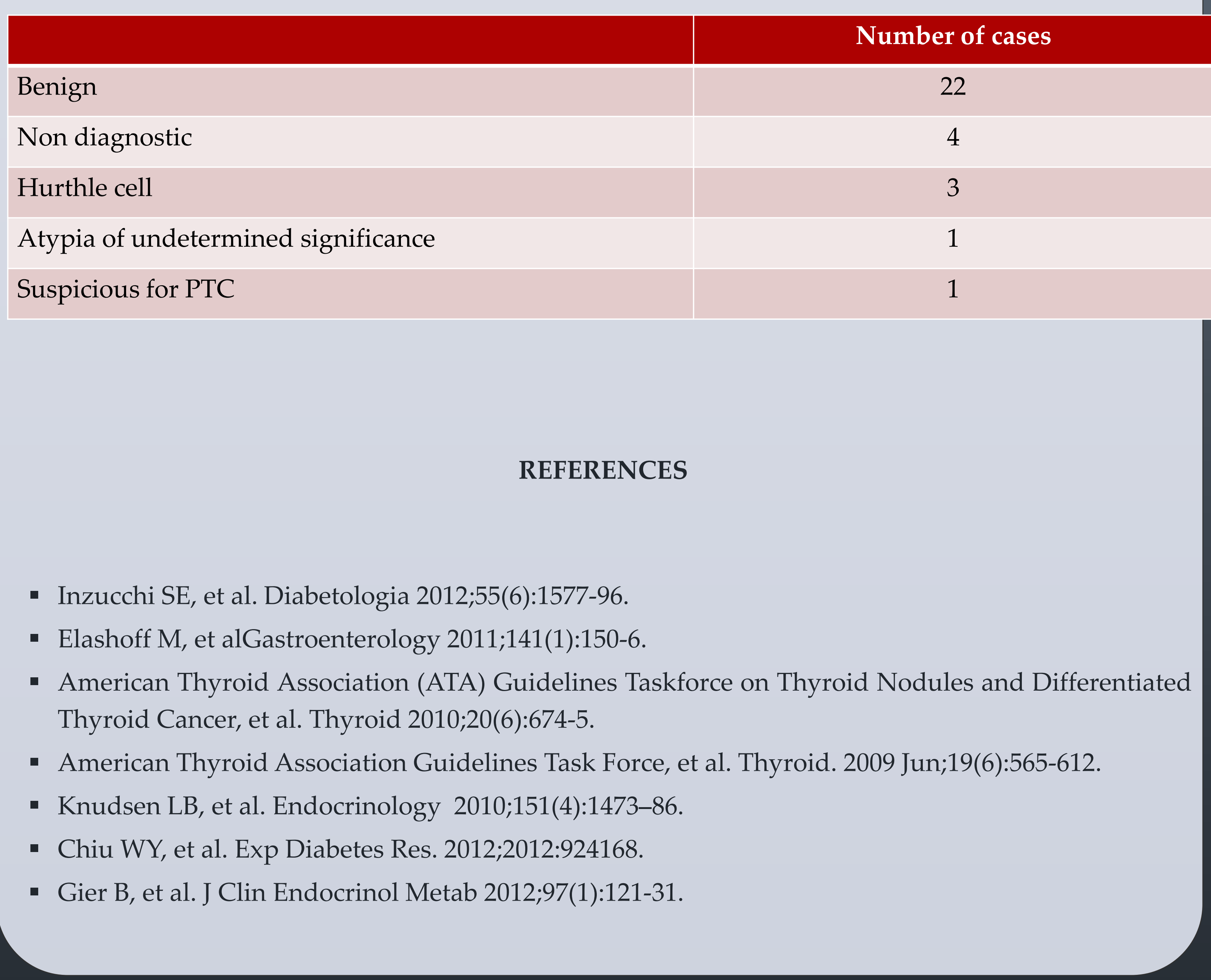

